\title{
The Paradigm Shift in the Disciplining of Village Cadres in China: From Mao to Xi
}

\author{
Juan Wang ${ }^{*}$ (1) and Yu Mou๋ ${ }^{\dagger}$ (1)
}

\begin{abstract}
Village cadres are important agents for the state yet disciplining them has been difficult. There are few disciplinary tools that can easily hold them to account. Prior to 2018, Party discipline did not apply to non-Party cadres. Legislation was ambiguous in relation to these grassroots agents and had to rely heavily on legal interpretation. The impact of the cadre evaluation system on village cadres, who are not considered to be public servants on the state payroll, was limited. This situation has changed since 2018. The party-state has consolidated and institutionalized ways in which grassroots cadres are checked and disciplined. Instead of relying on policy regulation, which had been the dominant disciplinary method since 1949 , village cadres are now fully subject to Party rules and state laws. These changes have been accomplished through the application of three measures. First, village Party secretaries are to serve concurrently as village heads, and members of village and Party committees are to overlap, thereby making them subject to Party discipline. Second, village cadres are now considered to be "public agents" and are on an equal legal footing with other state agents. Finally, a campaign waged by the criminal justice apparatus cleaned up village administration and prepared it for upcoming village elections in a new era.
\end{abstract}

Keywords: village cadres; discipline; law; institutionalization; village election; Xi Jinping

Village cadres are important agents for the state. They have been, and remain, at the forefront of Party and government policy implementation, including the implementation of highly unpopular policies such as unified grain purchase and sale (tonggou tongxiao 统购统销) and collectivization during the Mao era, and family planning in the reform period. They promote economic growth ${ }^{1}$ and provide public goods. ${ }^{2}$ At the same time, they are also the cause of societal

* Department of Political Science, McGill University, Montreal, Canada. Email: juan.wang2@mcgill.ca (corresponding author).

† School of Law, SOAS, University of London, London, UK. Email: ym19@soas.ac.uk.

1 Oi 1995.

2 Tsai 2007.

(C) The Author(s), 2021. Published by Cambridge University Press on behalf of SOAS University of London. This is an Open Access article,

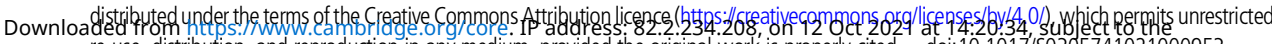


grievances. Charges of commandism and corruption have been commonplace. ${ }^{3}$ Some village cadres have connections with violent gangs. ${ }^{4}$ Some may even shift identities from state agents to societal representatives and facilitate collective resistance against higher-level state officials. ${ }^{5}$

Disciplining grassroots cadres in villages, however, has proved to be a daunting task. Despite a variety of disciplinary tools, such as Party disciplinary regulations, state laws and cadre evaluation systems, it has been tricky to hold grassroots cadres in villages to account. Party disciplinary regulations do not apply to cadres who are not Party members. Legal codes, especially anti-corruption laws, had to rely on legal interpretations that apply to these grassroots agents at the lowest level. The cadre evaluation system also had little impact because punitive measures such as salary deductions or demotion did not apply to village cadres as they were not considered to be public servants and were not on the state payroll.

There is scant scholarly research that systematically surveys the ways in which the party-state has disciplined these grassroots cadres. Relevant literature about local state agents in rural China can be categorized into three types. The first pays particular attention to the behavioural choices of Party officials at the county and township levels. ${ }^{6}$ The second examines village cadres and their interactions with or embeddedness in rural society at a particular time or through a case study. ${ }^{7}$ The third discusses the impact on village cadres and village administration of such policies as village elections, ${ }^{8}$ tax reforms, ${ }^{9}$ performance evaluation systems, ${ }^{10}$ or a combination of these policies. ${ }^{11}$

In this article, we compare and contrast the ways in which village grassroots cadres have been disciplined since 1949 and highlight the major changes introduced under the Xi Jinping 习近平 administration. First, village cadres, and particularly village heads, have been incorporated into the Party system and now formally serve concurrently as Party secretaries, making them subject to Party discipline. Second, village cadres are now considered to be "public agents" (gongzhi renyuan 公职人员) $)^{12}$ and thus are subject to the 2020 Law on Administrative Discipline for Public Agents (Gongzhi renyuan zhengwu chufen $f a$ 公职人员政务处分法). This change has not only clarified the position of village cadres as public agents according to state law but has also unequivocally placed them under the scrutiny of administrative sanctions and the state

3 Wedeman 1997; Xu and Yao 2015.

4 Hurst et al. 2014.

5 Wang, Juan 2012.

6 Heberer and Schubert 2006; Smith 2010; Zhou 2010.

7 Chan, Madsen and Unger 1992; Hinton 1966; Unger 1998.

8 Guo, Zhenglin, and Bernstein 2004; Oi and Rozelle 2000.

9 Zhang, Linxiu, et al. 2005.

10 O'Brien and Li 1999.

11 Wang, Juan 2012.

12 Public agents are not to be confused with civil servants (gongwu yuan), who are on the state payroll. We will discuss the legal concept of "public agents" below. 
supervisory apparatus. Third, as part of a campaign carried out by the criminal justice apparatus between 2018 and 2021, there was a major crackdown on grassroots cadres who associate with "black or evil forces."

In this article, we focus on disciplinary measures, by which we mean how the party-state sanctions and punishes miscreant village cadres. We do not examine the ways in which the party-state acquires information about the malfeasance of village cadres, such as the petition system and its Mao-era precedents which allowed the masses to report on government officials. ${ }^{13}$ Neither do we consider moral and ideological indoctrination, or punishment in the name of ideological training, such as self-criticism and confessions. ${ }^{14}$ Normative discipline is an important instrument of control but requires fuller explication as a separate project.

The remainder of this article analyses the disciplinary actions and reforms that affected village cadres between 1949 and 2012, from the beginning of the People's Republic of China until Xi Jinping rose to power. It suggests that policy guidelines and mass participation were the principal tools used to discipline grassroots cadres in the Mao era. During the reform period, numerous government regulations and various institutional reforms, such as village elections, fiscal reforms and petition systems, were enacted, but they largely focused on responding to policy grievances from farmers and potentially improving societal input instead of rectifying village cadres as a group. Since 2012, and since 2018 in particular, there has been an institutionalization and consolidation of the ways in which the party-state checks and disciplines these grassroots cadres, who have been formally incorporated into the Party and so are now subject to Party rules and state laws. There has been a recasting of the emphasis in disciplinary oversight in favour of three components, namely the "one shoulder pole" (yijiantiao 一肩 挑), the repositioning of village cadres as "public agents," and campaign-style justice. The article concludes that there has been a paradigm shift, from the Mao era to the $\mathrm{Xi}$ era, in the ways in which the party-state disciplines village cadres.

\section{Overview, 1949-2012}

Between 1949 and 2012, disciplinary measures aimed at grassroots cadres can be divided into policy regulations and mass movements (qunzhong yundong 群众运 动). ${ }^{15}$ During both the Mao and reform eras, policy regulations were used to warn against and punish improper behaviour of village cadres. There was only one mass movement that targeted grassroots cadres during this time, the Four Cleans campaign (siqing 四清). ${ }^{16}$

15 Some legislation was applied to village officials during this time period, but it was not specifically targeted at grassroots cadres. We review this legislation below.

16 Mass movements against village cadres also took place in 1947; however, the scope of the current paper is limited to the post-1949 period. 
Launched in $1963,{ }^{17}$ the Four Cleans campaign was the only mass movement that targeted village cadres. During the Mao era, several policy campaigns were initiated to address problems within the rural administration and among grassroots cadres. ${ }^{18}$ But the Four Cleans differed from previous campaigns in that it relied on mass movement tactics instead of policy regulations and administrative penalties. As discussed in Elizabeth Perry's contribution to this volume, millions of work-team members spent months in rural areas leading the campaign. ${ }^{19}$ The masses were mobilized to reason with and educate grassroots cadres during sessions which often turned into violent struggles. ${ }^{20}$

Policy regulations have commonly been used by the party-state to manage the illicit behaviour of village cadres. During the Mao era, many of the campaigns targeting miscreant grassroots cadres were accompanied by numerous policy directives. ${ }^{21}$ Between 1982 and 1986, the annual Central No. 1 Document on Rural Matters (Zhongyang nongcun gongzuo yihao wenjian 中央农村工作一号 文件), issued by the Central Party Committee and aimed at reforming the rural economy, abolished unified grain purchase and sale. Rural administration was expanded with the implementation of accompanying rural economic reforms and the establishment of township and village enterprises that were not always profitable. Such developments were financed by the excessive taxation of farmers. ${ }^{22}$ The widespread "three arbitraries" (sanluan 三乱) - arbitrary fees, fines and apportionments in rural areas - continued into the 1990s, exacting an increasingly heavy financial toll on farmers. ${ }^{23}$ Peasant complaints skyrocketed, ${ }^{24}$

17 We choose 1963 as the beginning of the Four Cleans campaign, as this was the year the Central Party Committee held its work meeting in February to discuss the Five Anti movement in urban areas and Four Cleans in rural areas. For an informative review, see Zhan and Chen 2009.

18 These campaigns were a response to charges of bureaucratism and commandism that initially appeared during grain collection and work assignment in rural areas (the Three Anti's, 1953), and a later stage of top-down inspection efforts targeting cadres (cadre inspection movement at the sub-county level, 1957), as well as in response to wide-spread suffering following the Great Leap Forward and famine (rectification movement, 1960).

19 Perry 2021.

20 Lin 2005; Baum and Teiwes 1968; Li, Ruojian 2005.

21 These include "Decisions regarding the rectification of Party grassroots organizations," promulgated during the First National Organizational Work Meeting (Guanyu zhengdun dangde jiceng zuzhi de jueyi) in April 1951; "Some regulations regarding the handling of violation of Party discipline by rural Party members," issued by the Central Party Committee Inspection Commission in 1956 (Guanyu chuli nongcun zhong gongchandangyuan weifan dang de jilü wenti de jixiang guiding); "Instructions regarding the beginning of the Three Anti movement in the rural areas," issued by the Central Party Committee in 1960 (Guanyu zai nongcun zhong kaizhan "sanfan" yundong de zhishi); "Opinions regarding a few policy issues related to the Three Anti movement in rural areas, by the Central Party Inspection Commission in 1960 (Guanyu nongcun "sanfang" yundong zhong jige juti zhengce wenti de yijian); "Decisions regarding some issues in current rural work (draft)" by the Central Party Committee in May 1963 (Guanyu muqian nongcun gongzuo zhong ruogan wenti de jueding (cao'an); and "Notice regarding some issues during the current socialist education movement in rural areas" by the Central Party Committee in December 1964 (Nongcun shehuizhuyi jiaoyu yundong zhong muqian tichu de yixie wenti de tongzhi).

22 Wang, Juan 2005.

23 Chen and Duan 2010.

24 Bianco 2001; O’Brien 2002; Bernstein and Lü 2003; Yu, Jianrong 2004; Yep 2002. 
and were consequentially followed by numerous regulations forbidding these arbitrary impositions by grassroots cadres. ${ }^{25}$

The party-state did not simply issue policies constraining the behaviour of grassroots cadres; it also engaged in various policy changes and institutional reforms to tackle the origins of farmers' grievances. The 1993 Law on Agriculture, for example, set limits on the arbitrary fees levied on peasants by capping the combined payment of formal township and village levies (often referred to as santi wutong 三提五统, or tongchou tiliu 统筹提留) at 5 per cent of the average net per capita income of residents for the preceding year. In practice, however, local cadres falsified statistics to continue levying excessive fees. ${ }^{26}$ The "Open governance and open finance in villages" initiative was another policy change, introduced by the General Office of the Chinese Communist Party (CCP) Central Committee together with the General Office of the State Council in April 1998. ${ }^{27}$ During the $\mathrm{Hu}-\mathrm{Wen}$ administration (2002-2012), farmers' protests continued, with grievances related to land expropriation, village financial disputes, peasant salary disputes and environmental issues. ${ }^{28}$ The administration responded by introducing fiscal reforms (the "tax-for-fee" reform in 2003 and the abolition of agricultural taxes in 2005), recentralizing land requisition authority to the county level, and bestowing oversight of village finances to township-level authorities. ${ }^{29}$

Yet one of the major initiatives of the $\mathrm{Hu}-\mathrm{Wen}$ era, the "Building a new socialist countryside" campaign, failed to launch any campaigns against corrupt village cadres. Annual No. 1 Documents issued between 2004 and 2012 discussed improving farmers' income by increasing technological and infrastructural investment, building modern agriculture and improving policies related to migrant workers; ${ }^{30}$ a few did make references to grassroots cadres, but the emphasis was on the "care and protection" (guanxin he aihu 关心和爱护) of these cadres, the improvement of their training in policies, laws and practical skills (2006), and the recruitment and promotion of Party secretaries from among veterans, returned migrant workers and economically savvy (zhifu nengshou 致富能手) Party members in order to offset “weak” (ruanruo huansan 软弱涣散) grassroots

25 For an informative review of policies, see Zhang, Jinsong 2005. The most notable ones include the 1985 Notice to prohibit "san luan"; the 1990 Notice to reduce farmers' burdens; the 1991 Regulations on farmers' burdens and labour; the 1992 Notice following up on the 1991 Regulations; the 1993 Urgent Notice about reducing farmers' burdens; the 1996 Decisions regarding reducing farmers' burdens; and the 1998 Decisions regarding a few issues related to agriculture and rural work.

26 He and Cheng 2001.

27 "Guanyu zai nongcun pubian shixing cunwu gongkai he minzhu guanli zhidu de tongzhi" (Notice regarding general implementation of open governance and democratic management in rural villages). Beijing Courts Database, 18 April 1998, http://fgcx.bjcourt.gov.cn:4601/law?fn=ch1098s113.txt\&dbt= chl. Accessed 20 September 2021.

28 Yu, Bin 2006; Sun, Jinglin 2010; Wang, Juan 2017, Table 1.1.

29 Wang, Juan 2017, Ch. 4.

30 "Jujiao zhongyang yi hao wenjian 2004-2021" (The Central Committee of the Chinese Communist Party Document No. 1, 2004-2021), The Ministry of Agriculture of the PRC, http://www.moa.gov. cn/ztzl/jj2021zyyhwj/. Accessed 2 June 2021. 
Party organizations (2010) and improve self-governance in building Party organizations in rural areas (2012).

Notable changes have taken place during the $\mathrm{Xi}$ administration. The overall focus of rural work, as evidenced by nine annual No. 1 Documents, has been on reducing poverty and attaining "moderate prosperity" (xiaokang 小康). The Party has, however, taken unprecedented institutional measures since 2018 to emphasize rural work. The 2019 CCP Rural Work Regulations (Zhongguo gongchandang nongcun gongzuo tiaoli 中国共产党农村工作条例, 2019 Rural Work Regulations hereafter), for example, formalized the holding of an annual Rural Work Meeting by the Party centre, and the formation of a leading small group on rural work led by the Politburo Standing Committee and staffed with a permanent office. Local Party committees at the county-level and above are also required to set up corresponding permanent small leading groups. ${ }^{31}$

In addition to this institution building, $\mathrm{Xi}$ has also consolidated the party-state's control over village cadres with three key components in Party regulations and state laws. The first, the proposed "one shoulder pole" (described below), will directly position village heads as concurrent Party branch secretaries and under Party scrutiny. Second, village cadres are now formally categorized as "public agents" and are on an equal footing with other state officials subject to the 2020 Law on Administrative Discipline for Public Agents. Third, judicial mobilization in the form of the "sweep away black forces and eradicating evil forces" campaign (saohei chu e 扫黑除恶, SABFEE hereafter) has facilitated rectification and reorganization of village administrations by means of criminal justice. We elaborate on these components below.

\section{"One Shoulder Pole": The Party Supplants the Self-governing Body}

The Party has always been conscientious about the leadership role of its Party members and branches in rural areas. The specific ways in which Party members and branches lead rural affairs and their relationship with the grassroots administration have changed over time. Under Xi Jinping's leadership, Party branch secretaries have, for the first time, been explicitly instructed to be elected as village heads through village elections, thereby blurring the boundary between the Party and grassroots administration.

During the Mao era, the Party relied on Party members and peasant associations to engage in rural work. Peasant associations were elected bodies for rural administration and were believed to be a remedy for corruption and ideological rightism. Poor peasant associations established before 1949 were replaced by peasant associations in 1950, which were then replaced in turn by grassroots

31 County-level small leading groups in charge of rural work had been set up previously, such as during the "Building a new socialist countryside" campaign, a policy initiative launched during Hu-Wen administration in 2006 (Ahlers and Schubert 2009). However, it was a temporary team instead of a permanent structure. For the full text of the 2019 Rural Work Regulations, see "Zhonggong zhongyang yinfa 'Zhongguo gongchandang nongcun gongzuo tiaoli'." Xinhuanet, 1 September 2019, http://www.gov. cn/zhengce/2019-09/01/content_5426319.htm. Accessed 1 May 2021. 
governments after Land Reform. ${ }^{32}$ When the Party estimated in May 1964 that one-third of power at the grassroots level had been hijacked by class enemies in rural China, ${ }^{33}$ new poor and lower-middle peasants associations were established to replace grassroots cadres. ${ }^{34}$

During the reform era, particularly when the Provisional Organic Law of Villagers' Committees (1988) introduced village-level elections, the relationship between village committees (VCs) as an elected body and village Party branches changed. In the 1990s, Party branches were seen as the "leading core" (lingdao hexin 领导核心) of rural organizations; since 2019, they are expected to exercise “comprehensive leadership" (quanmian lingdao 全面领导) over rural affairs. According to the Minutes of the National Symposium on the Building of Village-level Organizations (Quanguo cunji zuzhi jianshe gongzuo zuotan hui jiyao 全国村级组织建设工作座谈会纪要) held on 13 December 1990 (1990 Minutes hereafter), Party branches in villages were responsible for implementing Party policies, educating and evaluating cadres in collective enterprises, and "leading" (lingado 领导) VCs, village collective economic organizations, the youth league, women's organizations and the militia. This Party-VC relationship was reiterated in the 1999 "Regulations regarding the CCP rural grassroots-level organization work" (Zhongguo gongchandang nongcun jiceng zuzhi gongzuo tiaoli 中国共产党农村基层组织工作条例) (Articles 2 and 9). However, since the promulgation of the 2019 "Regulations regarding the CCP rural grassroots-level organization work" (2019 Organization Regulations hereafter), Party branches are no longer regarded as the "leading core"; instead, they now exercise "comprehensive leadership" over village affairs. ${ }^{35}$

The effect on personnel arrangements of the "comprehensive leadership" promoted in the 2019 Organization Regulations and the 2019 Rural Work Regulations appears to be that village Party secretaries should, "through legal procedures” (tongguo fading chengxu 通过法定程序), serve as both VC chair and manager of village collectively owned economic organizations. Membership of the two committees - Party committees and village committees - should overlap. Similarly, the 2019 No. 1 Document urged "full implementation" (quanmian tuixing 全面推行) of the practice of Party secretaries chairing village committees (i.e. the position of village head) through "legal procedures." 36

32 Zhang, Yinghong 2007.

33 Xia 2015.

34 "Guanyu zai wenti yanzhong de diqu you pinxie xingshi quanli de pishi" (Notice regarding poor and lower-middle peasant associations taking control in areas with serious issues). Xinhuanet, 12 November 2007, http://www.ce.cn/xwzx/gnsz/szyw/200706/13/t20070613_11731053.shtml. Accessed 26 April 2021

35 "Zhonggong zhongyang yinfa 'Zhongguo gongchangdang nongcun jiceng zuzhi gongzuo tiaoli"” (Central Committee of CCP publishes regulations on CCP rural grassroots-level organization work). Xinhuanet, 10 January 2019, http://www.xinhuanet.com/2019-01/10/c_1123973918.htm. Accessed 1 May 2021.

36 "Guanyu jiaqiang he gaijin xiangcun zhili de zhidao yijian" (The guidance on strengthening and improving village management). Xinhuanet, 23 June 2019, http://www.gov.cn/zhengce/2019-06/23/ content_5402625.htm. Accessed 2 May 2021. 
This practice of "one shoulder pole" - combining the post of the formally elected village head with that of the village Party secretary - has for decades been seen as a way to resolve the conflict between village Party branches and elected bodies. When the Organic Law on Village Committees came into effect in 1999, "one shoulder pole" pilot projects were conducted in Shandong, Guangdong and Hainan provinces. In 2002, shortly after these pilot programmes, the General Office of the Central Party Committee and the General Office of the State Council issued Document No. 14 (2002 Notice hereafter) to "encourage" (changdao 倡导) such practices, but implementation at a local level varied greatly across provinces. ${ }^{37}$ Given the heterogeneity of China's villages, it is certainly not the case that all Party secretaries have the upper hand, despite official support from their Party bosses at the township level. ${ }^{38}$ In villages where elections are held, scholars have noted both power-sharing ${ }^{39}$ and conflicts between Party secretaries and village heads. ${ }^{40}$

The 2019 Organization Regulations and the 2019 Rural Work Regulations, therefore, marked the first time that "one shoulder pole" was formally mandated to be "fully implemented" "through legal procedures." This was a major policy shift. According to the 1990 Minutes, leading members of the village Party branch could, through election, serve concurrently as head of the VC. The 2002 Notice "encouraged" (tichang 提倡) the practice of Party members being elected to VCs and Party secretary candidates standing for election as VC head. Only until they were elected could they be recommended to be Party secretaries. In contrast to the 2002 Notice, in which elected village heads were appointed as Party secretaries, the new practice aims to have Party secretaries elected as village heads, without specifying how to make it happen.

The "one shoulder pole" method is essentially jurisdiction manipulation, as observed by Ling $\mathrm{Li} .{ }^{41} \mathrm{Li}$ concludes that the Party can exert its control over state administration by placing exclusive jurisdiction over state affairs under the Party. The Party is in effect "gerrymandering," often by "combining offices and joint posts," or "one office with two plaques/hats," in cases in which a post or an institution under regulatory scrutiny is not a Party post or Party organization. However, there is a caveat: elected village heads have never officially been state agents. What we observe here is not simply a case of the Party under Xi taking control of state affairs; rather it is the Party taking control of affairs away from a self-governing, democratically elected body.

This raises the question of how, in practice, village Party secretaries can be guaranteed to be elected as village heads. In addition to the procedural and candidate manipulations documented elsewhere, ${ }^{42}$ anti-corruption measures have

\footnotetext{
37 Tang 2015.

38 Oi and Rozelle 2000.

39 Sun, Xin, et al. 2013; Fewsmith 2006.

40 Guo, Zhenglin, and Bernstein 2004.

41 Li, Ling 2020.

42 Wang, Zhongyuan 2020.
} 
emerged as complementary tools to eliminate alternative candidates. The 2019 No.1 Document instructed county-level governments to "re-examine" village elections (huitou kan 回头看) and to disqualify those village cadres and Party branch members with a criminal record or who were involved with black forces, previously identified as "village despots" (cunba 村霸) or “evil forces” according to the judicial criteria used during the SABFEE campaign. The 2020 No. 1 Document further emphasized the importance of anti-corruption work at the grassroots level to prevent the rise of "village despots."

We explicate the connections between the SABFEE campaign, corruption and elections in a later section. For now, it suffices to say that while such anti-corruption drives have the potential to improve the quality of Party-nominated candidates, they also provide a means to eliminate noncompliant ones. Should a Party branch secretary not be elected as the head of a VC, it is highly likely that the successful candidate will be subjected to a thorough vetting of his or her criminal background.

\section{"Public Agents": Affirmation of the Legal Status of Village Cadres}

Another major change that occurred in 2020 was the recategorization of village cadres as "public agents" so that they are now subject to the 2020 Law on Administrative Discipline for Public Agents. This change has not only clarified the position of village cadres as public agents by state law but has also placed them under the scrutiny of the administrative process and the state supervisory apparatus.

Legally speaking, village cadres have a complex position given their ambiguous status as a sui generis group. On the one hand, they are elected by members of village committees, which are defined as autonomous organizations (zizhi zuzhi 自治组织) according to Article 111 of the 2018 Constitution. As a self-governing organization, a village committee is not regarded as a public body and, for that reason, village cadres who chair and manage a village committee are not commonly considered to be public agents representing the state. ${ }^{43}$ On the other hand, village cadres are elected to carry out public services such as mediating disputes, maintaining public order and implementing public health and family planning policies (Article 7 of 2018 the Organic Law on Village Committees). Their role as head of the village committee inevitably entails public duties such as collecting fees and levies and keeping a close watch on those who are deprived of political rights. 44

Given that the ambiguous legal standing of village cadres did not fit squarely with that of a state agent, it was difficult to know under what legal jurisdiction

43 The autonomous status of village committees is further manifested in the 2018 Organic Law on Village Committees, which stipulates that the self-government and self-determination characteristic of village committees is supported by grassroots democracy in the forms of "democratic election, democratic decision-making, democratic management and democratic supervision." See the 2018 Constitution, Article 2 .

44 Benewick, Tong and Howell 2004. 
they came when punishing them for criminal acts such as corruption. It is true that village cadres who committed corruption-related crimes were subject to criminal sanctions prior to the 2020 Law on Administrative Discipline for Public Agents, which itself was not based on criminal law but rather on extended legislative interpretations passed in 1988 and $2000 .{ }^{45}$ For example, the charges of corruption and bribery could only be applied to village cadres in accordance with their role as "other personnel who manage public assets" (qita jingshou, guanli gonggongcaiwu de renyuan 其他经手、管理公共财物的人员) according to an additional interpretation published by the Standing Committee of the National People's Congress (NPC) in 1988.46 Similarly, the legislative interpretation passed in 2000 on the application of Article 93(2) held that village cadres could be charged and punished for corruption and embezzlement offences as state officials. ${ }^{47}$ Thousands of village cadres were indeed charged with and convicted of corruption on the basis of these legislative interpretations prior to 2019.48

At the same time, administrative regulations had a limited deterrent effect on sanctioning village cadres' misconduct. For example, the State Council's 1992 "Regulations governing the administration of the costs borne and services provided by peasants" (Nongmin chengdan feiyong he laowu guanli tiaoli 农民承担 费用和劳务管理条例) referenced both the 1990 “Regulations on administrative supervision” (Xingzheng jiancha tiaoli 行政监察条例) and the 1987 "Regulations on administrative penalties for public security" (Zhian guanli chufa tiaoli 治安管理处罚条例, 1987 Regulations hereafter) in its rules for disciplining village cadres who engaged in the "three arbitrary" activities. ${ }^{49}$ However, the punitive measures granted to administrative supervisory bodies - warning, demerit and demotion - lacked teeth when it came to village cadres. According to the 1987 Regulations, the police could only intervene in circumstances where assaults occurred and physical harm ensued, which limited the chances of bringing village cadres to account.

The 2020 Law on Administrative Discipline for Public Agents (2020 Law hereafter) was a turning point in this regard. For the first time, village cadres were officially classed as "public agents" and subject to disciplinary laws. The 2020

45 See Art. 1 of "The supplementary regulation on punishing crimes of corruption and bribery," promulgated by the NPC Standing Committee 1988. See also Art. 2 of the Supreme People's Court and the Supreme People's procuratorate on "The implementation of the supplementary regulation on punishing crimes of corruption and bribery" and the Standing Committee of the National People's Congress on Interpretation of Art. 93 (2), passed on 29 April 2000 and formally promulgated on 27 August 2009 by the NPC Standing Committee.

46 Ibid.

47 Ibid.

48 For example, the Conjoined Party Central Discipline Inspection Commission-State Supervisory Ministry announced that over 74,000 low-rank functionaries (or what the Chinese media call "flies") were disciplined in 2016. See "Gonggu fanfubai douzheng yadaoxing taishi" (Consolidating the anti-corruption position), China Discipline Inspection Commission Paper, 2 August 2017, https:// www.ccdi.gov.cn/special/sbjqcqh/jjqh_sbjqzqh/201702/t20170208_93669.html. Accessed 23 August 2021.

49 State council 1992. 
Law refers to the 2018 Supervision Law (jianchafa 监察法) for reference of the scope of "public agents" (Article 2). According to Article 15 of the 2018 Supervision Law, supervisory commissions are responsible for punishing the malfeasance of six categories of personnel, including personnel engaged in management at grassroots-level self-governance organizations, like village cadres.

To be sure, village cadres, in their role as "state agents" (guojia gongzuo renyuan 国家工作人员), were mentioned peripherally in law prior to the 2018 Supervision Law. Addressing Article 93 of 1997 Criminal Law, the NPC Standing Committee and the Supreme People's Court classified village committee personnel who assist the People's government in carrying out administrative work as "state agents" under limited circumstances. ${ }^{50}$ This decision, however, was more of a technical solution to a stand-alone legal issue as opposed to a political commitment. This is evidenced by the fact that the decision was primarily circulated within judicial organs and the NPC Standing Committee and was not published until 2009. ${ }^{51}$ By contrast, the current legal regime managing village cadres has not only adopted law as its primary format but has widely publicized the formal integration of village cadres as personnel under the oversight of supervisory agencies. ${ }^{52}$ Both judicial organs and the disciplinary apparatus are tasked with studying the 2020 Law. ${ }^{53}$

The paradigm shift in the legal regulation of village cadres in the $\mathrm{Xi}$ era is therefore unequivocal. Village cadres are now officially affirmed as state cadres and subject to criminal liability as well as administrative sanctions alongside other state agents. According to Article 22 of the 2020 Law, a variety of disciplinary measures can be applied to village cadres, including not only regular sanctions such as warnings and demerits but also more consequential ones such as cuts to bonuses and subsidies. As noted, the 2020 Law, in conjunction with the 2018 Supervision Law, has specifically declared village cadres to be public agents. This clarification of their legal categorization is important as it places village cadres on an equal footing with other government officials and thus subject to the same disciplinary procedures. It allows the supervisory commissions to impose administrative sanctions directly on village cadres, bringing the key players of the basic village communities firmly under the control of the party-state's supervisory authority.

50 More specifically, it is when they engaged in (1) management of disaster relief, flood control, poverty alleviation, migration management and public donations; (2) management of charity funds from public donations; (3) operation and management of state-owned land; (4) management of land expropriation compensation funds; (5) levying taxes; (6) work in relation to the one-child policy, household registration and conscription; and (7) other work in facilitating the administration of the local government. The Standing Committee of the National People's Congress on Interpretation of Article 93(2), passed on 29 April 2000 and formally promulgated on 27 August 2009.

51 See Standing Committee of the National People's Congress on Interpretation of Article 93(2), promulgated on 27 August 2009.

52 Changyuan 2020.

53 A simple search of "study, 2020 Law on Administrative Discipline for Public Agents" (xuexi gongzhi renyuan chufen $\mathrm{fa}$ ) yields over half a million results on the Baidu search engine. 


\section{Campaign Justice: Efficiently Cleaning Up Village Administration}

Since 2018, campaign-style enforcement has also been deployed to keep grassroots cadres in line. Although campaign-style enforcement by mass movement was used to discipline village cadres during the Four Cleans, mobilizing the criminal justice system to sanction village cadres is a new move. Launched in January 2018 to eliminate so-called black and evil forces (hei e shili 黑恶势力) and their “protective umbrellas” (baohusan 保护伞), the three-year SABFEE campaign removed thousands of village cadres from office. Convicted of black and evil crimes (hei e fanzui 黑恶犯罪), these dismissed cadres were stigmatized as criminals and "village despots" alike.

Some scholars have associated the SABFEE with the "strike hard" anti-crime movement launched in the mid-1980s. ${ }^{54}$ There are indeed similarities between the two: both targeted organized crime and emphasized efficient means to dispose of a large number of criminal cases. Politically motivated, these campaigns were directed by the party-state apparatus and supported by propaganda departments. However, unlike the "strike hard" campaign, which was aimed at cracking down on certain types of criminal activities, the SABFEE targeted specific groups of people. The CCP Central Office and the State Council declared that the campaign would wage war on (1) "black society" gangsters; (2) evil forces who use violence, threats or other means to bully the public and cause social disorder; and (3) their "protective umbrellas" (patronage networks) within the Party and the government, as well as Party committee members, government officials and members of the police force who fail to put in an effort to eliminate these criminal forces. ${ }^{55}$ Although village cadres were not explicitly targeted, they can be easily framed as having dealings with black and/or evil forces. ${ }^{56}$ Of these categories, "black force" crimes are well-established concepts in Chinese criminal law. According to Article 294 of the 2007 Criminal Law, whoever forms, leads or takes an active part in organizing criminal syndicates to commit organized illegal or criminal acts through violence, threat or other means shall be prosecuted for a mafia-style gang crime. The category of "evil force" crimes was introduced by a series of judicial interpretations based on the campaign guidelines. Those who commit evil force crimes are referred to as "frequently assembled criminal and unlawful organizations that are yet to be developed into mafia-style gangs [but] that carry out multiple criminal activities within a certain region or a certain industry through lording it over the people, perpetrating outrages, riding roughshod over people, and disrupting the economic order and people's daily

54 Wang, Peng 2020.

55 "Zhonggong zhongyang guowuyuan fachu guanyu kaizhan sao hei chu e zhuanxiang douzheng de tongzhi" (The Central Party Committee and State Council published notices concerning the implementation of the special action to sweep away black and evil forces). Xinhuanet, 24 January 2018, http:// www.xinhuanet.com/legal/2018-01/24/c_1122309773.htm. Accessed 3 June 2021; Zhu 2018.

56 "Zhonggong zhongyang bangongting, guowuyuan yinfa quanguo sao hei chu e zhuanxiang douzheng dudao gongzuo fang'an" (The Central Committee of CCP and State Council on publishing working plans on supervising the nationwide campaign to sweep away black and evil forces). Xinhuanet, 5 July 2018, http://www.gov.cn/zhengce/2018-07/05/content_5303847.htm. Accessed 6 June 2021. 
activities." ${ }^{57}$ Village cadres who have strong local connections, particularly in the form of clans, are likely to fall into these categories.

There are two interrelated reasons behind the inclusion of village cadres in the SABFEE campaign. The first is that some SABFEE targets overlapped with those of the "catching flies" component of Xi Jinping's anti-corruption campaign. According to the "Steering working plan of the nationwide SABFEE campaign," jointly issued in January 2018 by the general offices of the Party Central Committee and the State Council, SABFEE work was to be combined with the "catching flies" anti-corruption movement at the grassroots level..$^{58}$ Second, corruption at the grassroots level seems to be among a wide range of illicit dealings committed by or involving grassroots cadres. The National Discipline and Supervision Daily (Zhongguo jiijan jiancha bao 中国纪检监察报) reported that grassroots communities were among those hardest hit by crimes and unlawful activities committed by "black and evil forces" owing to the clan system, which supported local tyrants and "village despots." 59 The news report went on to suggest that the "specialized struggle" (zhuanxiang douzheng 专项斗争) against black and evil forces that had infiltrated the grassroots Party organizations was a "potent medicine" (mengyao 猛药) to treat the longstanding disease. Complementing Xi Jinping's anti-corruption drive, the campaign was undoubtedly a drastic move to manage grassroots cadres and strengthen the Party's governance at the basic level.

The connection between organized crimes in rural areas and village administration during the SABFEE campaign is a new development. In the reform era, various irregularities in rural governance were noticed by the central government, yet no action was taken to tackle these problems until 2018. In fact, in the 1990s, He Qinglian 何清涟, a well-known critic of Chinese economic and political reforms, warned that evil forces in the countryside in form of clans and hooligans had seized power through village elections and dominated Chinese rural politics. ${ }^{60}$ Ignoring He's warning, a number of No.1 Documents during the $\mathrm{Hu}-\mathrm{Wen}$ administration instead perceived issues of misgovernment and deepseated social ills in the countryside, such as prostitution, gambling and drug addiction, as "ugly social phenomena" (shehui chou e xianxiang 社会丑恶现象), which should be "strictly struck down" through village policing (nongcun jingwu jianshe 农村警务建设) (2006 No. 1 Document). Although rural electoral fraud, such as vote buying, and the interference of religious groups and clans in village public affairs were noted, the only vague solution suggested was to strengthen "instruction and leadership" (liangdao he zhidao 领导和指导) during the electoral cycle (2010 No. 1 Document).

\footnotetext{
57 "Guanyu banli e shili xingshi anjian ruogan wenti de yijian" (Notice concerning several questions on handling evil force cases). Xinhuanet, 9 April 2019, https:/www.spp.gov.cn/zdgz/201904/t20190409_ 414134.shtml. Accessed 10 May 2021.

58 Xinhuanet, 24 January 2018.

59 Zhai 2018.

60 He 1997.
} 
Although disciplining miscreant village cadres and cleaning up basic administration were some of the main objectives of the SABFEE campaign, the motivation of the campaign reflects the party-state's vision of rural governance and village elections. In August 2019, the general offices of the Central Party Committee and the State Council circulated the "Guiding opinion regarding strengthening and improving rural governance" (Guanyu jiaqiang he gaijin xiangcun zhili de zhidao yijian 关于加强和改进乡村治理的指导意见), which drew explicit links between the elimination of black and evil forces (including certain rural clan forces), rural governance and correcting village election fraud. It called for a crackdown on black and/or evil forces (alongside dominant clan forces) that manipulate and disrupt local Party committee elections and village committee elections. ${ }^{61}$ In line with the 2019 Document No.1, the 2019 Guiding Opinion underscores the importance of the election of village cadres through lawful means and the interlocking of members of grassroots Party committees with those of village committees. ${ }^{62}$

The SABFEE campaign achieved noteworthy results in rural areas. By the end of 2020 when the campaign was drawing to a close, over 41,700 village cadres had been expelled from village committees in disgrace. ${ }^{63}$ A total of 1,289 "black society" gang members and 14,027 "evil forces" in rural areas were convicted and punished after the three-year campaign, among which 3,727 were "village despots," purportedly responsible for eroding the governing effectiveness of basic Party organizations. ${ }^{64}$ In February 2021, the Commission for Deepening Overall Reform of the Central Party Committee issued mandates to institutionalize preventive measures to avoid the future rise of "village despots." ${ }^{65}$

\section{Conclusion: Paradigm Shift and Continuities}

Moving from the Mao era to the Xi era, there has been a paradigm shift in the ways in which the party-state disciplines village cadres. The constituent weight of three tools - policy regulations, mass movements and laws - has changed how the party-state is able to exert firm control over grassroots cadres through Party rules and state laws. What underpins the shift? Distinctive to the Xi Jinping administration, the party-state has promoted Party supremacy together with the institutionalization and standardization of state affairs ${ }^{66}$ and state-society relations. ${ }^{67}$ We maintain that changes related to village cadres form part of this broad reform

61 "Guanyu jiaqiang he gaijin xiangcun zhili de zhidao yijian" (The guidance on strengthening and improving village management). Xinhuanet, 23 June 2019, http://www.gov.cn/zhengce/2019-06/23/ content_5402625.htm. Accessed 2 May 2021.

62 Ibid.

63 Xiong 2020.

64 Yang et al. 2021.

65 "Guanyu chixu fangfan he zhengzhi 'cunba' wenti de yijian" (Opinions on continuously managing and preventing village despots). CNWest, 20 February 2021, http://m.cnwest.com/snyw/a/2021/02/20/ 19512611.html. Accessed 10 July 2021.

66 Guo, Baogang 2020.

$67 \mathrm{Fu}$ and Distelhorst 2018. 
that pulls the otherwise semi-outsider village cadres into the party-state apparatus, removing any lingering ambiguity about the autonomous status of village committees.

During the Mao era, policy directives were repeatedly issued with questionable effect. Then came the Four Cleans campaign during which laws and regulations were replaced with mass movements. For more than three decades (between the 1980s and early 2010s), policy directives were the primary instruments used to discipline village cadres, who remained marginal subjects of the law. Under the current Xi administration, laws that were side-lined in the 1960s have been brought to the fore not only by consolidating the legal status of village cadres as government officials but also via campaigns carried out by the criminal justice system. At the same time, the Party has tightened its control over village cadres by explicitly enforcing a nationwide reform of supplanting village leaders and committees with Party members and committees.

This is not to say that there are no elements of continuity from Mao to Xi. In fact, there have been deliberate moves to revisit past practices such as with the reinvention of the "Fengqiao experience" (fengqiao jingyan 枫桥经验). Well-known methods used during the Four Cleans campaign in Fengqiao District in Zhejiang included persuading "enemies" through reason (wendou 文 斗, i.e. struggle sessions), rather than using coercive measures (wudou 武斗, i.e. going through the criminal justice system), and using localized, massline solutions rather than relying on directives from above. ${ }^{68}$ The 2019 Organization Regulations and 2020 Document No. 1 have reinvented the "Fengqiao experience" for the "new era" in their emphasis on relying on the masses as sources of information and the local containment of social instability. In stark contrast to the discouragement of "coercion" in the 1960s, however, disciplining grassroots cadres in the present day underscores the importance of coercive powers, via the imposition of Party rules and state laws through which village cadres are to be sanctioned.

Party leadership is also being continued in the Xi era, but the Party's presence in rural governance has been strengthened by exercising "comprehensive leadership" in village affairs and taking over village committees in practice. The village election rules have recently been revised so that elections in villages and people's congresses at the township and village levels are to be synchronized and held every five years. ${ }^{69}$ Certain unauthorized behaviour that may potentially disturb

68 Zhuji County Party Committee 1964.

69 Art. 10 of the 2018 Organic Law of Village Committees has revised the tenure of VCs from three years to five years, corresponding to the elections of county and township people's congresses. Currently, village elections nationwide have been unified to be carried out in 2021. See "2021 nian cun ganbu huanjie xuanju you shenme bianhua" (What are the changes to the 2021 village cadre elections?). Tuliunet, 22 January 2021, https://www.tuliu.com/read-130430.html. Accessed 9 June 2021. At the same time, the first Organic Law of Urban Residential Committees (chengshi juminweiyuanhui zuizhi fa) was promulgated. There has been scant research comparing the urban councils with rural village committees through the relational lens of Party branches and elected bodies, with the notable exception of Benewick, Tong and Howell 2004. 
the process of election or influence the electoral outcome has been listed as illegal. ${ }^{70}$ After village elections in 2021, we can expect to see more village cadres holding concurrent posts in both village and Party committees.

Village cadres used to straddle two identities: state agents and societal representatives. Whereas it remains to be seen whether the paradigm shift towards formally constraining village cadres through Party rules and laws will make a significant difference in practice, the current emphasis on Party leadership and legal disciplinary measures seems to have drawn village cadres closer to being the lowest-level agents of the party-state.

\title{
Acknowledgements
}

We are grateful for the consistent support and insightful suggestions from Patricia Thornton, which greatly improved the quality of this article. Thanks also go to Xiaohong $\mathrm{Yu}$, Weimin Zuo and two anonymous reviewers for their helpful comments on earlier drafts.

\section{Conflicts of interest}

None.

\section{Biographical notes}

Juan WANG is associate professor of political science at McGill University. She writes on local governance, contentious politics, and law and politics in China.

$\mathrm{Yu} \mathrm{MOU} \mathrm{is} \mathrm{a} \mathrm{senior} \mathrm{lecturer} \mathrm{in} \mathrm{law} \mathrm{at} \mathrm{SOAS} \mathrm{University} \mathrm{of} \mathrm{London.} \mathrm{She}$ researches criminal law and criminal justice in China.

\begin{abstract}
摘要：对基层村干部的管理惩戒一直都是中国共产党国家治理的重要内容, 但是其困难之处在于针对基层村干部的惩戒手段较为有限。在 2018 年之前, 党内惩戒并不适用非党员的基层干部。法律条文也鲜有对村委会基层干部的 直接征戒措施, 不少制裁需要通过司法解释来实现。干部评审制度也不适用 于非国家公职人员的村干部。这种困境在 2018 年以后发生了显著的变化。基 层村干部近年来被逐步纳入党的制度化建设。对基层村干部的治理不再仅仅 作为政策层面的要求, 而是更多体现在党规和正式立法中。这种管理模式的 改变主要反映在三方面。首先, 村支书和村长一肩挑以及村委和党委成员的 重合让基层村干部直接受制于党规。其次, 基层村干部正式纳入国家公职人 员范畴。最后, 扫黑除恶专项斗争实现了对基层政权的清理, 为即将开展的 村干部换届选举工作铺平了道路。
\end{abstract}

关键词: 村干部; 法律; 基层治理; 制度化建设; 基层选举; 习近平 


\section{References}

Ahlers, Anna L., and Gunter Schubert. 2009. "'Building a new socialist countryside' - only a political slogan?" Journal of Current Chinese Affairs 38(4), 35-62.

Baum, Richard, and Frederick C. Teiwes. 1968. Ssu-Ch'ing: The Socialist Education Movement of 1962-1966. Berkeley, CA: University of California Center for Chinese Studies.

Benewick, Robert, Irene Tong and Jude Howell. 2004. "Self-governance and community: a preliminary comparison between villagers' committees and urban community councils." China Information 18(1), 11-28.

Bernstein, Thomas P., and Xiaobo Lü. 2003. Taxation without Representation in Contemporary Rural China. Cambridge: Cambridge University Press.

Bianco, Lucien. 2001. Peasants without the Party: Grass-roots Movements in Twentieth-century China, Asia and the Pacific. Armonk, NY: M.E. Sharpe.

Chan, Anita, Richard Madsen and Jonathan Unger. 1992. Chen Village under Mao and Deng. Vol. 2. Berkeley, CA: University of California Press.

Changyuan, Tianping. 2020. "Zhongbang! Cun ganbu bei zhengshi liewei guojia gongzhi renyuan! Chufen shiyong 'gongzhi renyuan chufen banfa" (Important: village cadres are listed as public agents and subject to the disciplinary measures of public agents). Pengpai News, $30 \mathrm{July,} \mathrm{https://}$ www.thepaper.cn/newsDetail_forward_8512055. Accessed 23 July 2021.

Chen, Jian, and Yan Duan. 2010. "1978-2006 nian Zhongguo nongmin fudan wenti yanjiu" (Research on the fiscal burdens on Chinese peasants, 1978-2006). Jianghan luntan 1, 34-38.

Dinghu, Gongzheng. 2020. "Guanyu zai sao hei chu e zhuanxiang douzheng zhong yanli daji ganrao pohuai cun (shequ) zuzhi huanjie xuanju xingwei de tonggao" (Notice regarding cracking down on activities that interfere with and harm village (community) organization elections during the special struggle to sweep away black forces and eliminate evil forces). Pengpai News, 28 December, https:/l m.thepaper.cn/newsDetail_forward_10573730. Accessed 5 July 2021.

Fewsmith, Joseph. 2006. "Institutional innovation at the grassroots level: two case studies." China Leadership Monitor 18, https://www.hoover.org/sites/default/files/uploads/documents/clm18_jf. pdf. Accessed 5 July 2021.

Fu, Diana, and Greg Distelhorst. 2018. "Grassroots participation and repression under Hu Jintao and Xi Jinping." The China Journal 79, 100-122.

Guo, Baogang. 2020. "A partocracy with Chinese characteristics: governance system reform under $\mathrm{Xi}$ Jinping." Journal of Contemporary China 29(126), 809-823.

Guo, Zhenglin, and Thomas Bernstein. 2004. "The impact of elections on the village structure of power: the relations between the village committes and the Party branches." Journal of Contemporary China 13(39), 257-275.

He, Qinglian. 1997. "Nongcun jiceng shehui difang e'shili de xingqi" (The rise of local evil forces in rural China). 21 Shiji 41, 129-134.

He, Qinglian, and Xiaonong Cheng. 2001. "Rural economy at a dead end: a dialogue on rural China, peasants, and agriculture." Modern China Studies 67(3), 7-8.

Heberer, Thomas, and Gunter Schubert. 2006. "County and township cadres as a strategic group: a new approach to political agency in China's local state.” Journal of Chinese Political Science 17(3), 221-249.

Hinton, William C. 1966. Fanshen: A Documentary of Revolution in a Chinese Village. Berkeley, CA: University of California Press.

Hurst, William, Mingxing Liu, Yongdong Liu and Ran Tao. 2014. "Reassessing collective petitioning in rural China: civic engagement, extra-state violence, and regional variation." Comparative Politics 46(4), 459-478.

Li, Ling. 2020. “The 'organizational weapon' of the Chinese Communist Party: China's disciplinary regime from Mao to Xi Jinping." In Rogier Creemers and Susan Trevaskes (eds.), Law and the Party in China: Ideology and Organisation. New York: Cambridge University Press, 187-213. 
Li, Qiuxue. 2009. Zhongguo xinfang shilun (The History of the Chinese Petition System). Beijing: Chinese Social Science Press.

Li, Ruojian. 2005. "Anquanfa: siqing yundong de qian gongneng” (Safety valve: the implicit function of the Four Cleans movement). Open Times 1, 112-126.

Lin, Xiaobo. 2005. "Siqing yundong shimo" (The movement trajectory of the Four Cleans). Dangshi tiandi 6, 42-46.

O'Brien, Kevin. 2002. "Collective action in the Chinese countryside." The China Quarterly 48, 139-154.

O’Brien, Kevin, and Lianjiang Li. 1999. "Selective policy implementation in rural China." Comparative Politics 31(2), 167-186.

Oi, Jean C. 1995. "The role of the local state in China's transitional economy." The China Quarterly $144,1132-49$.

Oi, Jean C., and Scott Rozelle. 2000. "Elections and power: the locus of decision-making in Chinese villages." The China Quarterly 162, 513-539.

Perry, Elizabeth J. 2021. "Missionaries of the Party: work team participation and intellectual incorporation." The China Quarterly. DOI: https://doi.org/10.1017/S0305741021000618.

Smith, Graeme. 2010. "The hollow state: rural governance in China.” The China Quarterly 203, 601-618.

State Council. 1992. "Nongmin chengdan feiyong he laowu guanli tiaoli" (Regulations governing the administration of the costs borne and services provided by peasants), 41, 1430-34, http://www.gov. cn/gongbao/shuju/1991/gwyb199141.pdf. Accessed 17 July 2021.

Sun, Jinglin. 2010. "Suifei gaige hou nongcun xinfang de yizhong leixing: yi Henan sheng Fugou xian wei li" (A type of rural petition after the fiscal reforms - a case study of Fugou County, Henan). Remin xinfang 8, 37.

Sun, Xin, Travis J. Warner, Dali Yang and Mingxing Liu. 2013. "Patterns of authority and governance in rural China: who's in charge? Why?" Journal of Contemporary China 22(83), 733-754.

Tang, Ming. 2015. "Lun nongcun cunji zuzhi fuzeren dangzheng 'yijiantiao"” (A discussion on the "one shoulder pole" for village organization leadership in the countryside). Dangdai shijie shehuizhuyi wenti 1, 3-26.

Thornton, Patricia A. 2007. Disciplining the State: Virtue, Violence, and State-making in Modern China. Cambridge, MA: Harvard University Press.

Tsai, Lily L. 2007. Accountability without Democracy: How Solidary Groups Provide Public Goods in China. Cambridge: Cambridge University Press.

Unger, Jonathan. 1998. "Cultural revolution conflict in the villages." The China Quarterly 153, 82106.

Wang, Juan. 2005. "Going beyond township and village enterprises in rural China." Journal of Contemporary China 14(42), 177-187.

Wang, Juan. 2012. "Shifting boundaries between the state and society: village cadres as new activists in collective petition." The China Quarterly 211, 697-717.

Wang, Juan. 2017. The Sinews of State Power: The Rise and Demise of the Coherent Local State in Rural China. New York: Oxford University Press.

Wang, Juan. 2018. "What's wrong with corruption? Messages from confession in China." Crime, Law and Social Change 69(3), 447-463.

Wang, Peng. 2020. "Politics of crime control: how campaign-style law enforcement sustains authoritarian rule in China." The British Journal of Criminology 60(2), 422-443.

Wang, Zhongyuan. 2020. Remodeling Democracy: Managed Elections and Mobilized Representation in Chinese Local Congresses. Washington, DC: Lexington Books.

Wedeman, Andrew. 1997. "Stealing from the farmers: institutional corruption and the 1992 IOU crisis." The China Quarterly 152, 805-831.

Xia, Fei. 2015. "Mao Zedong yu shehuizhuyi jiaoyu yundong" (Mao Zedong and the socialist education movement). People's net, 14 September, http://dangshi.people.com.cn/n/2015/0914/ c85037-27580547-5.html. Accessed 6 May 2021. 
Xiong, Feng. 2020. 'Zhongquan daji 'cunba' gonggu zhizheng genji: sao hei chu e zhuanxiang douzheng dadiao nongcun shehei zuzhi 1198 ge" (A heavy blow to village despots and the consolidation of grassroots foundation: the campaign to sweep away black and evil forces eliminated 1,198 rural criminal organizations). Xinhuanet, 15 December, http://www.xinhuanet.com/legal/2020-12/ 15/c_1126864310.htm. Accessed 7 June 2021.

$\mathrm{Xu}$, Yiqing, and Yang Yao. 2015. "Informal institutions, collective action, and public investment in rural China." American Political Science Review 109(2), 371-391.

Yang, Weihan, et al. 2021. "Leiting liangjian: quanguo sao hei chu e zhuanxiang douzheng jishi" (Thunder and lightning swords: on-the-spot report of the special struggle to sweep away black forces and eliminate evil forces). Xinhuanet, 28 March, http://www.xinhuanet.com/politics/ 2021-03/28/c_1127265425.htm. Accessed 9 June 2021.

Yep, Ray. 2002. "Maintaining stability in rural China: challenges and responses." Center for Northeastern Asian Policy Studies, The Brookings Institute, https://www.brookings.edu/research/ maintaining-stability-in-rural-china-challenges-and-responses/.

$\mathrm{Yu}$, Bin. 2006. "Nongcun shehui wending xingshi yanjun, ping'an jianshe cheng ganbu kaohe yiju" (Rural social stability situation dire, stability continues to be standard cadre evaluation measure). Liaowang xinwen zhoukan, 28 November, http://www.snzg.cn/article/2006/1128/article_2902.html.

$\mathrm{Yu}$, Jianrong. 2004. "Jiushi niandai yilai de nongmin weiquan kangzheng" (Farmers' rights-based protests since the 1990s). 21 Shiji 86, 53-61.

Zhai, Duo. 2018. "Sao hei chu e, jiaqiang jiceng zhengquan jianshe hen zhongyao" (It is very important to sweep away and eliminate black and evil forces and to strengthen grassroots organization building). Zhongguo jijian jiancha bao, 10 July, https://www.ccdi.gov.cn/yaowen/201807/ t20180710_175360.html. Accessed 10 June 2021.

Zhan, Fengtao, and Jinzuo Chen. 2009. "Shehuizhuyi jiaoyu yundong yanjiu shuping" (A review of studies of the socialist education movement). Fujian dangshi yuekan 2, 26-28.

Zhang, Jinsong. 2005. "Jianqing nongmin fudan de gonggong zhengce fenxi" (An analysis of the public policy on reducing farmers' burdens). Chinese Public Administration 3, 100-04.

Zhang, Linxiu, Yuanyuan Yan, Loren Brandt and Scott Rozelle. 2005. "China - rural public finance: the village perspective." World Bank Reports, https://fsi-live.s3.us-west-1.amazonaws.com/ s3fs-public/Village_Finance_2005.pdf. Accessed 6 June 2021.

Zhang, Yinghong. 2007. "Zhongguo nonghui de lishi kaocha" (The history of peasant associations in China). Zhongguo gaige bao, 17 April, http://www.aisixiang.com/data/22411.html. Accessed 21 July 2021.

Zhou, Xueguang. 2010. "The institutional logic of collusion among local governments in China." Modern China 36(1), 47-78.

Zhu, Jicha. 2018. "Zai sao hei chu e zhuanxiang douzheng zhong zhongdian chachu sanlei wenti" (The notice concerning strengthening the supervisory responsibility of discipline inspection in the special action to sweep away and eliminate black and evil forces). Xinhuanet, 13 February, http://www.xinhuanet.com/2018-02/13/c_1122415668.htm. Accessed 17 August 2021.

Zhuji County Party Committee. 1964. "Zhujixian Fengqiao qu shehuizhuyi jiaoyu yundong zhong kaizhan duidi douzheng de jingyan" (The experiences of struggling against enemies during the socialist education movement at Fengqiao district, Zhuji county). Renmin jingcha, 9-11. 